\title{
RESEARCH
}

Open Access

\section{Romanian legal management rules limit wood production in Norway spruce and beech forests}

Olivier Bouriaud ${ }^{1 *} \mathbb{D}$, Gheorghe Marin ${ }^{1}$, Laura Bouriaud ${ }^{2}$, Dominik Hessenmöller $^{3}$ and Ernst-Detlef Schulze ${ }^{3}$

\begin{abstract}
Background: The quantitative impact of forest management on forests' wood resource was evaluated for Picea and Fagus mixed forests. The effects on the productivity of tendering operations, thinnings and rotation length have seldom been directly quantified on landscape scale.
\end{abstract}

Methods: Two sites of similar fertility but subject to contrasted forest management were studied with detailed inventories: one in Germany, the other in Romania, and compared with the respective national forest inventories. In Romania, regulations impose very long rotations, low thinnings and a period of no-cut before harvest. In contrast, tending and thinnings are frequent and intense in Germany. Harvests start much earlier and must avoid clear cutting but maintain a permanent forest cover with natural regeneration. While Germany has an average annual wood increment representative for Central Europe, Romania represents the average for Eastern Europe.

Results: The lack of tending and thinning in the Romanian site resulted in twice as many trees per hectare as in the German site for the same age. The productivity in Romanian production forests was $20 \%$ lower than in Germany despite a similar fertility. The results were supported by the data from the national forest inventory of each country, which confirmed that the same differential exists at country scale. Furthermore, provided the difference in rotation length, two crops are harvested in Germany when only one is harvested in Romania. The

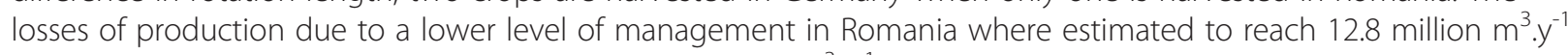
in regular mountain production forests, and to 15 million $\mathrm{m}^{3} . \mathrm{y}^{-1}$ if managed protection forest is included.

Conclusions: The productivity of Picea and Fagus mountain forests in Romania is severely depressed by the lack of tending and thinning, by overly long rotations and the existence of a 25-years no-cut period prior to harvest. The average standing volume in Germany was 50 \% lower than in Romania, but the higher harvesting rate resulted in more than doubling wood production. Considering the mitigation effects of climate change by forests, it emerges that the increase in standing volume of forests in Romania is smaller than the additional harvest in Germany which serves fossil fuel substitution.

Keywords: Forest management, Forest productivity, Legal rules, Sylviculture, Forest, Operations, Wood resource

\footnotetext{
* Correspondence: obouriaud@gmail.com

${ }^{1}$ National Forest Inventory, National Research and Development Institute for

Forestry INCDS, Eroilor Bd. 128, Voluntari, Romania

Full list of author information is available at the end of the article
} 


\section{Background}

Forests are expected to provide an increasing number of ecosystem services to society while environmental stresses and public demands increase in pressure (van der Plas et al. 2016). The choice of suitable forest management is more crucial than ever in order to match often contradicting social demands. As a measure of climate protection, increasing the carbon stocks is one major global target, even though sustainable harvest of wood may also contribute to climate mitigation by replacing oil-based products.

There is a large body of literature reporting an increase of forest productivity in relation to environmental changes (e.g. Charru et al. 2010; Pretzsch et al. 2014). Research has focused on the consequences of the recent changes in land use and ownership (Houghton 2003), mainly in the tropics and post-socialist countries (Kuemmerle et al. 2007, 2008). Also, the influence of climate and nitrogen deposition on forest productivity has been amply studied (de Vries et al. 2009; Janssens et al. 2010) but the influence of forest management for non-plantation forests has received comparatively little attention despite its proven importance (Seidl et al. 2011a; Noormets et al. 2015; Vetter et al. 2005). The comparison at large scales of contrasting management practices and their consequences on wood resource and forest productivity has seldom been undertaken (Campioli et al. 2015; Naudts et al. 2016). While several studies have aimed at estimating the impact of changing forest management on the forest resource based on models (Pussinen et al. 2009; Hynynen et al. 2015; Schelhaas et al. 2015), to our best knowledge there are no studies comparing the impact of current management based on real inventory data.

Forest management largely determines the characteristics, the state and variations of the growing stocks of wood resources. In production forests, the main objectives regarding the production of wood are to:

- supply trees of certain dimension for construction as required by the wood market over a reasonable time period with minimal waste;

- maintain stand wood volume and stem density at a level such that canopy packing still allows light to penetrate deep into the canopy and maximize stand productivity;

- harvest trees as young as possible to reduce the risk of stand failure by biotic and abiotic factors.

While these objectives could call for a relative homogeneity of the forest management prescriptions, great differences in forest management exist between countries.

In Romania, forest management has been strongly influenced by the nationalization of all forests in 1952 when they went under state ownership. The necessity to pay the war reparations to USSR during the period 1946-1956 has led to major harvests, often in form of large-scale clear cuts and plantings. The harvests still exceeded allowable cut frequently (1951-1955; 19621975; 1976-1979; 1980-1984), and the cuttings were concentrated mainly on accessible forests (Popescu et al. 2004). Excessive harvests occurred despite fairly restrictive technical norms of management implemented through management plans that had been renewed every 10 years in all forests since the end of the 1950's. In 1987, in reaction to over-harvesting, a new forest law was issued (Law nr. 2/1987) implementing low thinning, long rotations -exceeding 100 years for all main forest species with associated large tree dimensions- and prohibiting large-scale clear-cuts. Romania currently implements a "cut and leave" management with little care at an early age, slow individual growth due to overcrowding, and a final clear cut at a very advanced age (Schulze et al., 2014). The forest law adopted in 2008 (Forest Code 2008) and modified later in 2015 did not bring important changes in this sylvicultural system, but some new rules were adopted to stimulate the realisation of thinnings in the earlier stages of the stands.

In contrast, in other European countries that also experienced post-war over-use of forests, management was more liberal because of a larger range of ownerships, while state-owned forest were not dominant (Bouriaud et al. 2013). Under these conditions, more emphasis was given to a sustainable supply of wood for a growing market with the consequence of early care and harvest at an early age.

The first objective of the present study was to compare the productivity (annual volume growth) of two Picea and Fagus mixed forests of several hundred hectares growing under contrasted regimes of forest management but similar ecological conditions, one in Romania and one in Germany (in the following designated as the RO and D sites), used here as a baseline. Secondly, based on the respective National Forest Inventories data, we aimed at quantifying the consequences of governmental regulations on the forest resource and its productivity. Besides the data availability criteria, the countries were chosen as to represent average wood increments in Central Europe (Germany) and in Eastern Europe (Romania) (TBFRA2000, Ťupek et al. 2010).

\section{Methods}

\section{Study sites}

\section{The Hermannsberg forest site, Germany}

The study-site Hermannsberg forest $\left(50^{\circ} 42^{\prime} \mathrm{N}, 10^{\circ} 36^{\prime} \mathrm{E}\right)$ is a Devonian volcano at the southern slope of the Thüringerwald Mountains that separate the German state of Thüringia in the North from Bavaria in the South. Base rock is Rhyolite and volcanic tuff. The study site covers 
200 ha that extends from 500 to about $900 \mathrm{~m}$ elevation a.s.l. Mean annual precipitation is 800 to $1200 \mathrm{~mm}$ with a maximum in summer. Mean annual temperature is about $7{ }^{\circ} \mathrm{C}$. Soils are Cambisols and Podzols.

\section{The Boișoara forest site, Romania}

The study-site is the Boişoara forest located in the Făgăraş Mountains of the southern bow of the Carpathian Mountains $\left(45^{\circ} 29^{\prime} \mathrm{N}, 24^{\circ} 27^{\prime} \mathrm{E}\right)$. The site covers 500 ha that ranges between 790 and $1715 \mathrm{~m}$ a.s.l. The mountains are composed of crystalline gneisses and micaschist. Soils are Dystric Cambisols and Lithic Leptosol at low elevation, and brown Podzols at high elevation. Mean annual temperature is about $8{ }^{\circ} \mathrm{C}$; annual precipitation is 700 to $800 \mathrm{~mm}$, with maximum precipitation in summer.

\section{Site conditions}

Abundance-dominance surveys were carried out in 2014. Both regions had an identical number of herbaceous species (208 species), 88 of which were obligate forest species in Boișoara, but only 51 obligate forest species were found at Hermannsberg. The Ellenberg-based indicator value for soil acidity (R-value) was $5.98 \pm 1.15$ ( \pm SD) at Boișoara and $5.30 \pm 1.5$ at Hermannsberg. The Ellenberg-based indicator for nitrogen supply was the same at both sites with an average $N$-value of $5.3 \pm$ 1.5 at Boişoara and $5.5 \pm 1.6$ at Hermannsberg. There were no meteorological stations close enough to provide data, but interpolated gridded data (AGRI4CAST; http://mars.jrc.ec.europa.eu/mars) show that the sum of precipitations during the growing season (April to August) was identical at both sites during the last 30 years, being around $300 \mathrm{~mm}$. The difference in yearly sums was driven by fall and winter precipitations only.

Thus the site conditions are very similar between sites, despite the difference in elevation, compensated by the more northern latitude of Germany. The mean dominant tree height estimated at 60 years was remarkably similar for both sites: $25.76 \pm 0.36 \mathrm{~m}$ at Boișoara and $25.70 \pm$ $0.40 \mathrm{~m}$ at Hermannsberg (Fig. 1). The site index at both sites was therefore comparable.

The forest composition is also very similar with $30 \%$ of the wood volume being Fagus and 60 \% Picea at Boișoara and with $20 \%$ of the wood volume being broadleaved trees and $80 \%$ conifers at Hermannsberg. The diversity of broadleaved trees was larger at Hermannsberg: the inventories revealed the presence of 21 tree species against only 13 at Boișoara.

\section{Assessment of wood volume}

The study is based in on a systematic grid-based inventory conducted at $100 \mathrm{~m} \times 100 \mathrm{~m}$ at Hermannsberg, and $200 \mathrm{~m} \times 200 \mathrm{~m}$ at Boişoara. At each site, 200 plots were

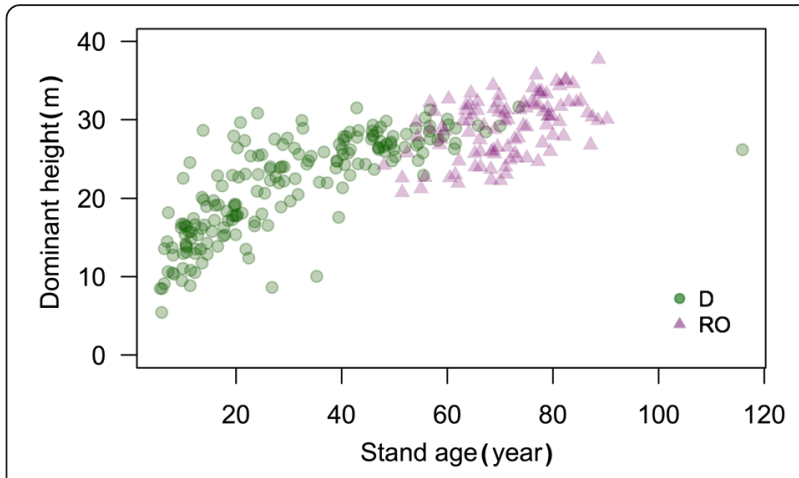

Fig. 1 Comparison of the dominant height (mean of the 4 largest trees per plot) against stand age at both sites

established in 2014. Each plot consisted of 3 concentric circles of 6,9 and $13 \mathrm{~m}$ radius $\left(113,250\right.$, and $\left.530 \mathrm{~m}^{2}\right)$ for small, medium size and large trees respectively. The diameter at breast height (DBH), top height and position of all stems with $\mathrm{DBH}>5 \mathrm{~cm}$ were recorded to the nearest $0.1 \mathrm{~m}$, using a hypsometer (Vertex, Haglöf AB, Sweden). Slope angle was taken into account when projecting field data onto plots of horizontal orientation. The methodology of the inventory was strictly identical at both sites. The conversion into wood volume follows species-specific allometric relationships based on DBH and height (Wirth et al. 2004; Döbbler et al. 2006).

\section{Assessment of productivity}

Bark-to-pith increment cores were taken at breast height at both sites using the same sampling scheme. One core per tree was extracted from a subset of trees within each plot. Three cores for each species were collected: one dominant, one codominant, one dominated tree. The cores were air dried then mounted on wooden supports and sanded. The tree rings were measured and cross-dated using the CDendro package (Cybis Elektronik and Data, Sweden) from scanned images (2400 dpi). The diameter increment of the last 10 years was measured from these tree-ring cores using the method presented in Bakker (2005).

The reconstructed diameter was used to estimate the plot-level cumulated volume increment during the last 10 years. To this end, a linear mixed-effects model was fit on the individual 10-years increment observed on the trees cored with a random plot effect, then applied to all inventoried trees for each plot (Babst et al., 2014a, b). Following Jucker et al. (2015) the model was developed as a function of tree size at the time of the inventory and a random plot effect in R (3.2.2; R Development Core Team 2015) using the package lme4 (Bates et al. 2014):

$$
\log \left(\Delta V_{i}\right)=\alpha_{j[i]}+\beta_{1} \log \left(V_{i}\right)+\beta_{2} h_{i}+\varepsilon_{i}
$$

where $\Delta V_{i}, V_{i}$ and $h_{i}$ are the 10-years volume increment, the current volume and the total height of tree $i$ growing 
in plot $j ; \alpha_{j}$ is the plot-level random species-specific growth rate in plot $j$; and $\varepsilon_{i}$ is the residual error assumed to be normally distributed.

\section{National forest inventory data}

The nation-wide average productivity $\left(\mathrm{m}^{3} \cdot \mathrm{ha}^{-1} \cdot \mathrm{yr}^{-1}\right)$ of beech and spruce stands per age classes were obtained from the German National Forest Inventory (BWI https://bwi.info). For Romania, the productivity per age classes was estimated based on the first National Forest Inventory (NFI) cycle measurements. For these estimations we considered exclusively mountain spruce- and beech-dominated stands that are used for wood production. Therefore, forest stands under protection regime or with protective function (where the principal management goal is to offer protection against e.g. landslides, watershed, steep slopes) were excluded for the main analysis. However, since these forests are also managed, they also contribute to the wood market. We therefore added an estimate that includes managed protection forest in our discussion of the results. Our study focusses on two countries of average wood increments representing Central versus Eastern Europe (TBFRA-2000, Ťupek et al. 2010), thus, the comparison has a regional dimension.

\section{Forest management description}

In Thüringia, the federal state that regulates management at Hermannsberg, there are only a few legal constraints for forest management: (1) clear cuts are not permitted for stands younger than 50 years in conifer and younger than 80 years in broadleaved stands, and (2) it is not permitted to reduce the stand volume below $40 \%$ of the volume of production tables in young stands though exceptions are possible at demand (Thüringer Waldgesetz 2008).

The management of spruce begins when stand density drops below about 1.800 stems.ha ${ }^{-1}$ up to a canopy height of $2 \mathrm{~m}$. At a DBH of 7 to $15 \mathrm{~cm}$, about 60 to 100 "future trees" per hectare are promoted by removing competitors. Thinning is already economical, i.e. it has market value. The aim of the management is a continuous-cover forestry regime, with natural regeneration under shelter, to minimize the expenditure for regeneration. Harvesting is based on the economic conditions. In spruce-dominated forests, trees should be harvested at a diameter lower than $35 \mathrm{~cm}$. For this reason, most stems are harvested at an age $<80$ years. Stems are mainly sold as logs in $4 \mathrm{~m}$ and $5 \mathrm{~m}$ lengths. Clear cuts are possible, but they are subject to permission by the forest administration. The overall objective is to harvest as early as possible, but to avoid clear cuts and plantations, and to maintain a permanent forest cover with natural regeneration.

In Romania, the forest law (Forest Code 2008) and the system of 8 volumes of technical norms regulate the management of all forests, irrespective of ownership. Boișoara forest management is therefore prescribed in detail by law. The thinning operations should start when forest stand mean DBH is $>10 \mathrm{~cm}$ and canopy cover is at least $90 \%$. However, the stand volume (not number of trees) can only be reduced, according to the official technical norms, by a maximum of $18 \%$ for spruce and a maximum of $17 \%$ for beech every 10 years, which of course can hardly be operationalised in situ. This likely results in removing the "best" trees to make the operation viable. By law, at $2 / 3$ of the rotation period (generally at age 75 ), the stand enters into a 25 years "freeze" period, where no forest operation is permitted, besides sanitary cuttings. Eventually, at age 100 stands can enter into a phase of final harvest, but only $1 / 3-1 / 7$ of the volume can be harvested by law every 10 years, depending on the ecological conditions and stand composition. Harvest may be by clear cutting (but only for pure spruce stands) or by selective cutting. Thus, at the time of its final harvest the stand may be as old as 170 years, when trees reached $>50 \mathrm{~cm} \mathrm{DBH}$, and most stems are rotten in the core or have red heart. Trees are cut to the length of healthy stems (rotten stem bases are left in the forest if there is no demand for firewood from the local communities) and are generally transported as long wood to the main roads.

\section{Results}

The Romanian (RO) stands have twice the volume per hectare as stands of Germany (D) at $\sim 20 \%$ of the growth rate (Fig. 2a). Productivity (annual volume growth) reached a low maximum in RO $\left(\sim 150 \mathrm{~m}^{3} \cdot \mathrm{ha}^{-1}\right.$ per 10 years $)$ while $\mathrm{D}$ stands generally operated at a linear increment of growth/ volume reaching a maximum of more than $250 \mathrm{~m}^{3} \cdot \mathrm{ha}^{-1}$ over 10 years. The average volume increment at national level estimated by the NFIs confirmed the great difference in productivity levels, with 80 versus $150 \mathrm{~m}^{3} \cdot \mathrm{ha}^{-1}$ over 10 years in Romania versus Germany (Fig. 2b, Table 1). The data also confirmed the generality of the results observed in the two study sites. The D site even seemed to be slightly below the national level. As a result of differences in management rules, the practical rotation is twice as long in Romania than in Germany, therefore two tree crops are harvested in Germany when only one is harvested in Romania.

Based on the difference of the volume growth as measured by the national inventories between Romania and Germany, we estimated a "volume-loss" for the Romanian situation, assuming that the growth conditions are generally similar for spruce and beech. The estimate is based on the areal extent of different volume classes (Table 2). The total loss in growth is estimated to be about 12.8 million $\mathrm{m}^{3}$.year ${ }^{-1}$ (61 \% of the current national production) taking into account only the beech and spruce 

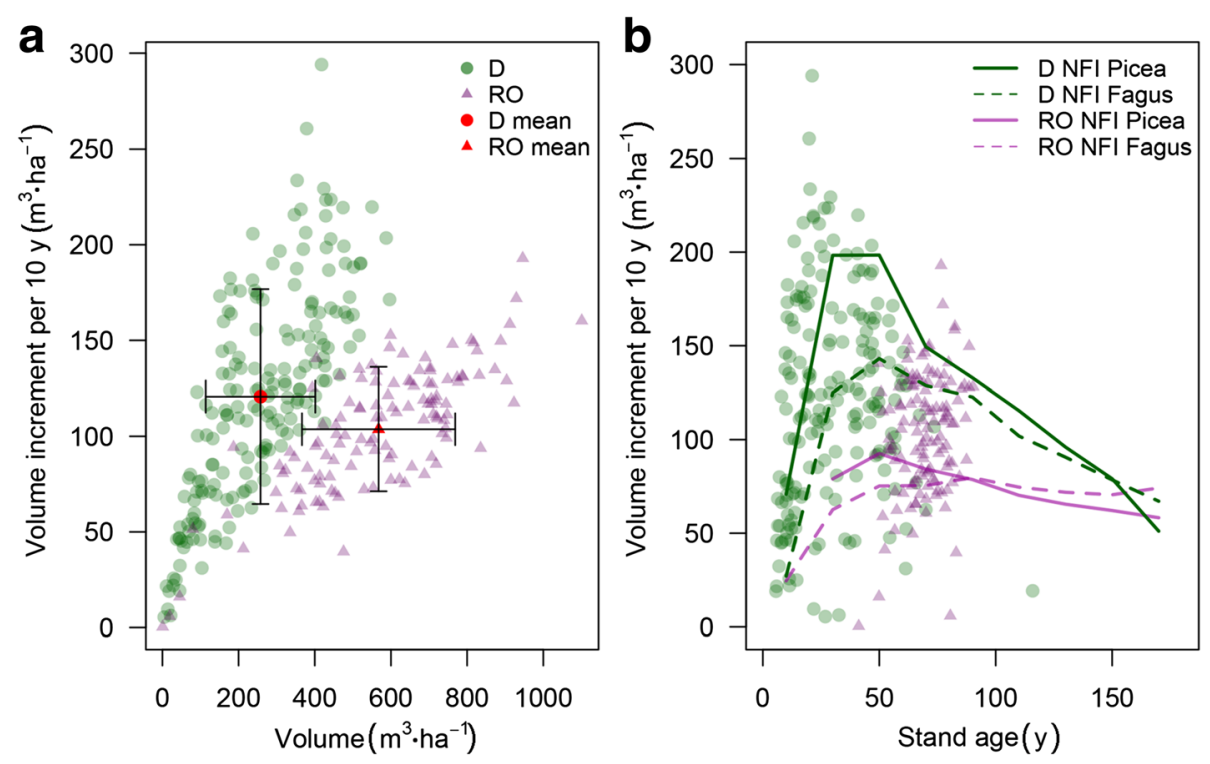

Fig. 2 a Volume increment per 10 years as related to standing stand volume on the $D$ and $R O$ sites. Red dots represent mean site values, bars 1 SD; b Volume increment per 10 years as related to stand age. The NFI data for Germany and Romania are superposed (solid and dashed lines) for comparison

Table 1 Area, productivity per age classes of beech and spruce mountain forests in Romania according to the national forest inventory, and productivity losses in Romania

\begin{tabular}{|c|c|c|c|c|c|}
\hline & Age classes & $\begin{array}{l}\text { Area in Romania } \\
\text { (ha) }\end{array}$ & $\begin{array}{l}\text { Productivity in Romania } \\
\left(\mathrm{m}^{3} \cdot \mathrm{ha}^{-1} \cdot \mathrm{y}^{-1}\right)\end{array}$ & $\begin{array}{l}\text { Productivity in Germany } \\
\left(\mathrm{m}^{3} \cdot \mathrm{ha}^{-1} \cdot \mathrm{y}^{-1}\right)\end{array}$ & $\begin{array}{l}\text { Productivity losses: } \\
\text { Area } \times(\text { productivity in } \mathrm{D} \text { - productivity in } \mathrm{RO}) \\
\left(\mathrm{m}^{3} \cdot \mathrm{ha}^{-1} \cdot \mathrm{y}^{-1}\right)\end{array}$ \\
\hline \multirow[t]{10}{*}{ Picea } & $0-20$ & 103356 & 1.4 & 7.1 & 590879 \\
\hline & $21-40$ & 218082 & 7.9 & 19.8 & 2607939 \\
\hline & $41-60$ & 212645 & 9.3 & 19.8 & 2247676 \\
\hline & $61-80$ & 199526 & 8.4 & 14.9 & 1295376 \\
\hline & $81-100$ & 149529 & 7.9 & 13.3 & 810740 \\
\hline & $101-120$ & 78967 & 7.0 & 11.5 & 355919 \\
\hline & $121-140$ & 23255 & 6.6 & 9.6 & 71278 \\
\hline & $141-160$ & 7308 & 6.2 & 7.9 & 12332 \\
\hline & $>160$ & 1528 & 5.8 & 5.1 & -1097 \\
\hline & Sum & 994195 & & & 7991042 \\
\hline \multirow[t]{10}{*}{ Fagus } & $0-20$ & 130149 & 2.5 & 2.7 & 32908 \\
\hline & $21-40$ & 162552 & 6.3 & 12.5 & 1014201 \\
\hline & $41-60$ & 154291 & 7.5 & 14.3 & 1047098 \\
\hline & $61-80$ & 216615 & 7.5 & 12.9 & 1152395 \\
\hline & $81-100$ & 219061 & 8.0 & 12.3 & 942052 \\
\hline & $101-120$ & 174170 & 7.5 & 10.2 & 473749 \\
\hline & $121-140$ & 74316 & 7.2 & 9.1 & 139145 \\
\hline & $141-160$ & 38770 & 7.1 & 7.9 & 30856 \\
\hline & $>160$ & 20036 & 7.4 & 6.7 & -14137 \\
\hline & Sum & 1189959 & & & 12809309 \\
\hline
\end{tabular}


Table 2 Fit statistics of the model of productivity

\begin{tabular}{lrrrl}
\hline & Estimate & Std. error & $t$ value & $\operatorname{Pr}(>|t|)$ \\
\hline Intercept $($ site RO) & -34.5520 & 12.2379 & -2.823 & 0.005 \\
Volume $\left(\mathrm{m}^{3} \cdot \mathrm{ha}^{-1}\right)$ & 0.2192 & 0.0116 & 18.845 & $<2 \mathrm{e}-16$ \\
Density $\left(\right.$ trees $\left.\cdot \mathrm{ha}^{-1}\right)$ & 0.0152 & 0.0038 & 4.032 & $7 \mathrm{e}-05$ \\
Age (years) & -0.0079 & 0.1751 & -0.045 & 0.9639 \\
Management (site D) & 70.3157 & 7.0975 & 9.907 & $<2 \mathrm{e}-16$ \\
Density x management & 0.0158 & 0.0047 & 3.288 & 0.0011 \\
\hline
\end{tabular}

mountain forests used for wood production ( 2.2 million ha), hence not accounting for the protected forests. The loss increases to 15 million $\mathrm{m}^{3} \cdot \mathrm{year}^{-1}$ if managed protection forest is included.

The lower productivity in RO stand is mostly due to the difference in management which results in a higher average stand age. Figure $2 \mathrm{~b}$ shows that $\mathrm{RO}$ is twice as old as D forest: on average 70 versus 30 years. The inventory data also point out to a lack of stands younger than $\sim 40$ years in average in $\mathrm{RO}$, while stands more than 80 years old on average are very common. $\mathrm{RO}$ as well as $\mathrm{D}$ show a high variability of growth at similar age.

The mean stand density over the two sites (Fig. 3a) was very similar despite the 40 years difference in age. The decrease in density showed almost the same pattern but with a 40 year shift. Stands volumes in RO site at a given age are up to twice as high as in D but high volumes are achieved at much earlier ages in Germany due to earlier and more intense thinning.

The tree diameter histogram showed a shift towards larger diameters at the RO site (Fig. 4). The continuous decrease of frequency when diameter increases was visible in $\mathrm{D}$ but not in $\mathrm{RO}$, which indicates overmature stands.
A generalized linear model fit on the inventory data of the two sites suggested that productivity (volume increment over the last 10 years) was primarily influenced by the management factor while the stand volume, stand age and density had a much smaller, though significant, influence (Table 2). According to the model, the impact of the management accounts for $\sim 80 \mathrm{~m}^{3} \cdot \mathrm{ha}^{-1}$.

\section{Discussion}

The production of aboveground woody biomass in Romanian production forests was half that of German forests for the same standing volume despite a similar fertility and climate. Harvest rules and differences in rotation length are such that 2 tree crops are harvested in Germany during the time necessary to harvest 1 in Romania. Estimating the wood balance over the rotation length of RO, the difference in stand volume between $\mathrm{RO}$ and $\mathrm{D}$ of about $300 \mathrm{~m}^{3} \cdot \mathrm{ha}^{-1}$ is compensated by more than factor 2 by a higher rate of harvest in $\mathrm{D}$ versus RO. In D about $1400 \mathrm{~m}^{3} \cdot \mathrm{ha}^{-1}$ are harvested over two rotations as compared to about $700 \mathrm{~m}^{3} \cdot \mathrm{ha}^{-1}$ harvested in $R$. The national level features confirmed these regional findings and pointed to a productivity loss of 12.8 million $\mathrm{m}^{3} \cdot$ year $^{-1}$ for the Fagus and Picea forests used primarily for wood production, which represents about $25 \%$ of Romanian forests yearly production at country level. This difference increases to more than 15 million $\mathrm{m}^{3} \cdot$ year $^{-1}$ if managed protection forests are included in the comparison. The potential productivity in both countries may not be strictly equivalent, though large-scale studies point to very similar NPP values (e.g. Tupek et al. 2010; Bellassen et al. 2011; Babst et al. 2013). But small differences in potential productivity cannot explain the twofold discrepancy pointed out here.

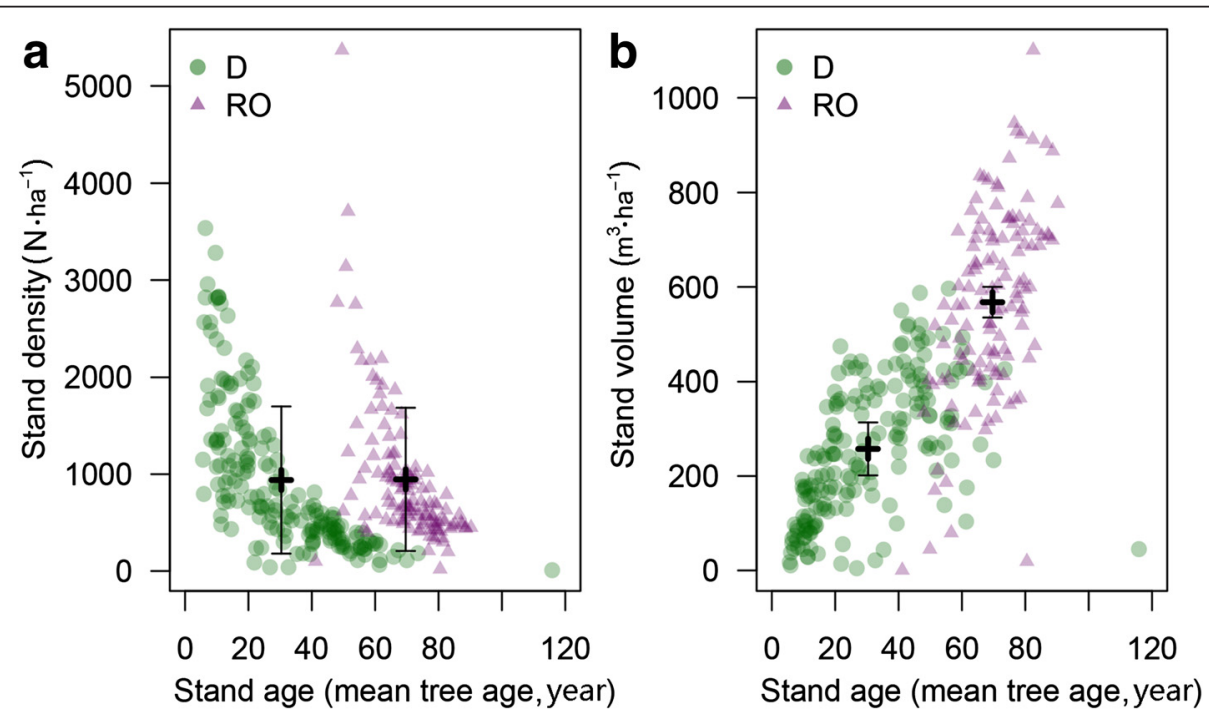

Fig. 3 Stand density (a) and stand volume (b) as related to mean stand age for the study sites. Crosses represent the mean values ( \pm 1 SD) 


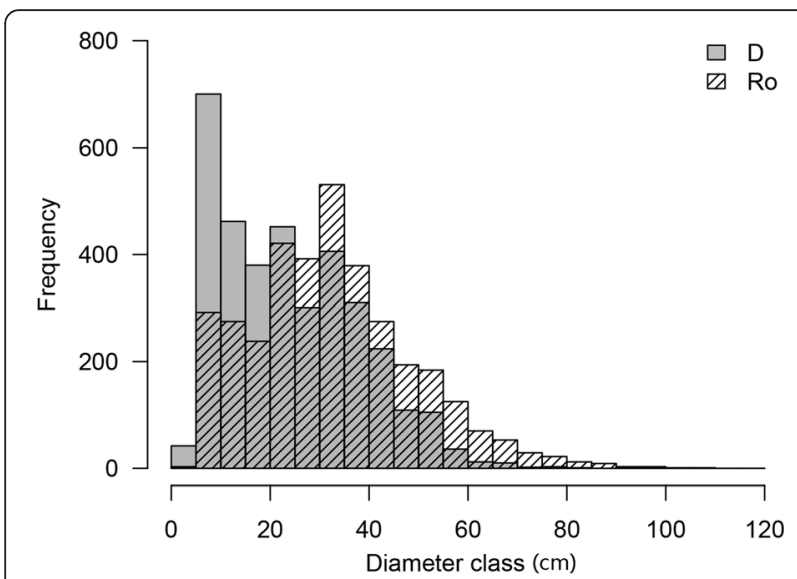

Fig. 4 Comparison of the frequency distribution of tree $\mathrm{DBH}$ at both sites

This study also showed that the overall productivity of forest stands can be much improved by tending and thinning. These observations are in line with Mund et al. (2002) who report stem growth in spruce much higher than yield table's predictions due to early thinnings. If thinned at a later age, trees cannot recuperate and achieve the same level of growth at a given stand density. Nutrient limitation of some physiological age- or size-related constraints could feature and explain this loss (Coomes et al. 2012). Our results support the idea that wider spacing and thinning maximize individual growth (Campioli et al. 2015), even enhancing stand-level productivity at large scales throughout a stands' life.

Four aspects of the forest management explained the large difference of productivity: i) different types of regeneration, i.e. natural before harvest (D) vs plantation after harvest (RO), the lack of tending, the lack of thinning; ii) the delayed harvests; iii) by freezing any management (as prescribed by the technical norms), during a period of 25 years at a time, when forest stands already reached the optimum dimensions for commercial use and only salvage cuttings are allowed; and iv) a harvest approach taking over 30-70 years to be completed. The "freeze" period of "no management" is of special concern: 25 years may be short for the lifetime of a tree, but it is a long period for management and essential for economic reasons. Basically it is equivalent to the average employment duration of a forest engineer.

The tending and the thinning operations realised in Germany resulted in a much faster initial growth of the stands (Mund et al. 2002), which were kept far below the self-thinning state. This management follows the simplest principle of sylviculture, whereby the growth is concentrated on few selected individuals. Optimal growth is favourable to the health of the trees and reduces the risk of insect attack or wind throw. The beneficial effects of thinning on tree growth and stand productivity can be explained by the increase of the water and nutrient resources available to the remaining trees. The amount of light that is intercepted by trees crowns increases, which further increases the tree-level efficiency (Aussenac 2000; Forrester et al. 2013). Thus the remaining trees have a more extended crown, which is also important in stabilizing against wind damage (Burschel and Huss 2003). Reduced canopy cover leads to less rain interception (Aussenac \& Granier 1988) and reduced transpiration (Bréda et al. 1995; Simonin et al. 2007; Lagergren et al. 2008). Altogether the water resources are improved, even if only temporarily. For these reasons, limiting the growing stock in forests by increasing the harvest volumes and frequency has been promoted as a mean to reduce forest vulnerability to climate change, wind or insect damages (Seidl et al. 2011a, b). The improvement of the soil water conditions after thinning can help the stand survive water stress events which are predicted to become more prominent with climate change. If the somewhat pessimistic climatic preditions made for European forests become true, with more frequent and intense droughts (Spellmann et al. 2015), such aspects need to be accounted for in the management of future forests.

The forest governance in Romania is based on the forest management plans, which are established every 10 years and prescribe the intensity and the volume to be extracted in every stand. We observed a large discrepancy between grid-based inventory data and the wood volumes documented in the Romanian management plan (Fig. 5). While inventory data detect very high volumes, the equivalent numbers in the management plan never go beyond an artificial threshold of $450 \mathrm{~m}^{3} \cdot \mathrm{ha}^{-1}$, irrespective of the stand age. Thus an increasing gap exists between the management plan and the existing biomass in the forest with increasing age, which by present regulations cannot be harvested legally. This gap practically precludes adequate tending and thinning. With the stand volumes being severely underestimated, the harvestable volume allowed as a fixed fraction of the volume stated in the management plan is also underestimated. This gap therefore is a strong incentive for illegal cutting, because biomass cannot be harvested without offending the 10-year plan and management basis. In addition, trees of high commercial value cannot be harvested at the time when the freezing period starts. In practice, sanitation cuttings are used as cover up for extracting valuable healthy trees because they meet their maximum commercial value, typically before the prescribed harvesting age and diameter, thus encouraging illegal logging (Bouriaud and Marzano 2014). Thus, proper governance and proper inventories, which could be done in the future from airborne instruments (Levick et al. 2016), would help to overcome illegal cutting. In addition, the fact that Romanian forestry is 


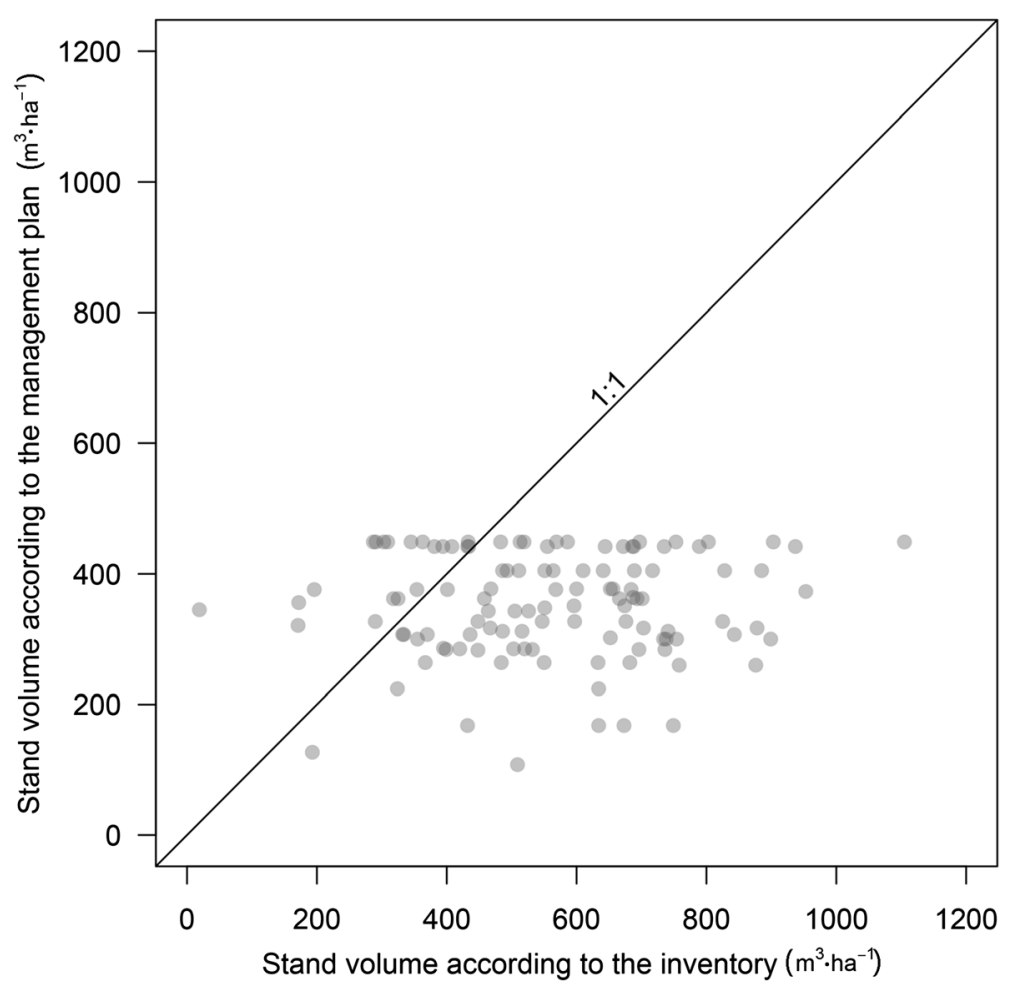

Fig. 5 Comparison of the stand volumes recorded in the management plan and a grid-based inventory in Boișoara

driven by a complicated system of forest laws and regulations of forest activities in both the public and private sector is a recognised source of corruption and illegal logging (Callister 1999; Contreras-Hermosilla 2002).

Comparing the national inventory data of Germany and Romania production forests (forests for which the primary goal is producing wood) we estimate that Romania may in fact lose about 13 million $\mathrm{m}^{3}$ per year in production forest and about 15 million $\mathrm{m}^{3}$ of wood growth annually if managed protection forests are included. This is a large number, to be handled with care, because it is based on a broad comparison of two national inventories. However, we are convinced that the order of magnitude is correct. In the present estimate we used the productivity of Germany as a base line, because these data are available, and both countries represent Central vs Eastern Europe respectively in their forest growth (TBFRA-2000). The present estimate is based on the current age structure of Picea and Fagus mountain forest stands in Romania with wood production as a primary goal, which have a fair share of old stands (over $19 \%$ are more than 100 years old). As a result of the very long rotations, in Romania the age-structure of forest becomes unbalanced with a high proportion of old stands and an understocking of young stands. A different regulation would result in a different age structure with more young stands, which would then offer a much larger productivity and more adaptability to climate change (Bouriaud and Marzano 2014), because the forest composition can be changed at twice the rate in D compared to RO.

While suggesting to shorten the rotation length in production forests, we point at the effects of present management regulations on the age structure which is highly unbalanced. Shortening the rotation length, for instance by skipping the current no-cut period, would help to avoid clear cuttings, and to limit the illegal flow of timber coming from uncontrolled sanitation cuttings. In Germany the open canopy cover of old stands allows for natural regeneration before harvest rather than of plantations after felling of dense old stands. Thus, with proper management, the clear felling could be abandoned even in Norway spruce stands (Thueringen 2015). An increased productivity would also mean that more forest could be put under protection by land-sharing without affecting the country-level wood supply.

Even though our study is based only on two intensively studied sites and on two national inventories, we like to point out that the implications go far beyond Romania and Germany. The "cut and leave"- type of management (Schulze et al. 2014) is probably true for most of the boreal forest globally, and it is probably true for the tropics. Shortening the rotation will result in concerns on 
the provision of the ecological services including sequestering carbon. The value of standing wood volume as a mitigation strategy for climate change versus replacing fossil fuel products by wood remain under debate (Nabuurs et al. 2007; Naudts et al. 2016). Forestry fulfils the social demands for wood, fibre and energy, and therefore is a key component in the climate negotiations. According to Paris protocol, national emissions are balanced by the forest sink including forest products (i.e. the harvested wood). The higher contribution to the wood market in D overtops the higher standing biomass in $\mathrm{RO}$ about by factor 2. Thus, the climate mitigation effort via replacing fossil fuel increases with management.

In present times, forest management needs to serve not only the international conventions on climate change but also the biodiversity convention. It has been shown that biodiversity is not affected by a proper management system, it is equal to or even increases in managed forests beyond the level of protected forests (Paillet et al. 2010). Although shortening the rotation would probably be subject of critical opinions, and disadvantages (precautions to be taken into consideration) are discussed in literature (e.g. Hansen et al. 1991; Schulze et al., 2012), we argue that it will not conflict with the biodiversity convention. According to our knowledge, based on recent examples on forests with similar conditions but much shorter rotations, the biodiversity in the managed systems is higher than in unmanaged systems, even for endangered species (Schulze et al. 2016). Gossner et al. (2016) show that the diversity of decomposing fungi and insects was mainly determined by the kind of wood species rather than by the amount of wood, and the most attractive wood species were confined to managed forest. Fungi were more diverse in managed forest (Goldmann et al. 2016). With increased harvests by proper management, the management would also improve the resilience against pests and climate extremes, and ensure a continued water supply. Thus all the main forest services are met and even improved by proper management which includes tending, thinning and decision on the rotation length.

It is worth considering if the situation in Romania could be changed. The basis for a mitigation policy would be to support "future trees" and reduce stand density in an early stage, since it would improve productivity according to our results. This would provide more wood to the market without depressing the forest stock. However, these objectives cannot be reached by the forest manager without a legal basis. It is mainly the current technical norms that prohibit mitigation in Romania. Sanitary cuttings, essentially implemented to remove trees damaged by bark beetles and windthrows, cannot be in excess of $15 \%$ of the standing volume, which is too low to be economical. Therefore, cuttings are either not realised or push owners to go illegally beyond $15 \%$. The freezing period should also be abandoned as it prohibits harvests at the moment when trees reached their maximum economical value. Thus, it is not only the prescriptions upon thinning in the earlier age but also the "freeze" between 100 and 125 years that hinder mitigation. In addition, the management plans should not perpetuate existing growth rates, but be based on achievable growth under best practice of management, and the burden of proof for sustainability needs to be brought by local management and not by the government. In summary mitigation must start at the governmental regulations and constraints. The problems that were presented here for Romanian forests may exist in other regions of the world and may be considered globally in countries with constrained management rules as well as countries having experienced historic over-use.

\section{Conclusion}

By comparing two sites of equivalent fertility, in combination with the national inventories of Romania and Germany, we show that the lack of sylvicultural operations at young age resulted in a considerable loss of productivity in Romania. The extreme rotation length in Romania results in a negative feedback on productivity and age structure of Romanian forests. The results from our study suggest that inappropriate management imposed by the rule of law results in a considerable loss of timber. We discuss the implications of inappropriate management on biodiversity and stand stability, and we are concerned that this situation may enhance illegal operations because the value of wood decreases with rotation length.

\section{Acknowledgements \\ Authors are thankful to Iulian Dănilă, Ulrich Pruchitzki for their valuable help during the inventory. We thank Gheorghe Ștefan for the tree-rings preparation and measurement. We thank Adrian Indreica, University of Brasov, and Reiner Boecker, Uni Hohenheim, for help with plant identification, and Ludwig Leidinger for help with processing the data. We thank Dr Shawn Levick for editorial comments on the manuscript. $\mathrm{OB}$ acknowledges support by a grant of the Romanian National Authority for Scientific Research, CNCS-UEFISCDI, project number PN-II-ID-PCE-2011-3-0781. LB acknowledges support by a grant of the Romanian National Authority for Scientific Research, CNCS - UEFISCDI, project number PN-II-RU-TE-2014-4-0017.}

\section{Authors' contributions}

$\mathrm{OB}$ and EDS designed the study. OB and EDS analysed the field data and contributed to writing the paper. GM, LB and DH contributed to writing the paper. All authors contributed to the interpretation and discussion of the results. All authors read and approved the final manuscript.

\section{Competing interests}

The authors declare no competing interests.

\section{Author details}

${ }^{1}$ National Forest Inventory, National Research and Development Institute for Forestry INCDS, Eroilor Bd. 128, Voluntari, Romania. ${ }^{2}$ University Stefan cel Mare Suceava, Romania, Universitatii str. 13, Suceava 720229, Romania. ${ }^{3}$ Department of Biogeochemical Processes, Max Planck Institute for Biogeochemistry, Hans-Knoell-Str. 10, Jena 07745, Germany. 
Received: 15 March 2016 Accepted: 22 August 2016 Published online: 02 September 2016

\section{References}

Aussenac G (2000) Interactions between forest stands and microclimate: ecophysiological aspects and consequences for silviculture. Ann For Sci 57(3):287-301

Aussenac G, Granier A (1988) Effects of thinning on water stress and growth in Douglas-fir. Can J For Res 18(1):100-105

Babst F, Poulter B, Trouet V, Tan K, Neuwirth B, Wilson R, Carrer M, Grabner M, Tegel W, Levanic T, Panayotov M, Urbinati C, Bouriaud O, Ciais P, Frank D (2013) Site- and species-specific responses of forest growth to climate across the European continent. Glob Ecol Biogeogr 22(6):706-717

Babst F, Bouriaud O, Alexander R, Trouet V, Frank D (2014a) Toward consistent measurements of carbon accumulation: A multi-site assessment of biomass and basal area increment across Europe. Dendrochronologia 32:153-161

Babst F, Bouriaud O, Papale D, Gielen B, Janssens IA, Nikinmaa E, Ibrom A, Wu J, Bernhofer C, Kostner B, Grunwald T, Seufert G, Ciais P, Frank D (2014b) Above-ground woody carbon sequestration measured from tree rings is coherent with net ecosystem productivity at five eddy-covariance sites. New Phytologist 201:1289-1303

Bakker JD (2005) A new, proportional method for reconstructing historical tree diameters. Can J For Res 35(10):2515-2520

Bates D, Maechler M, Bolker B, Walker S (2014) Ime4: Linear mixed-effects models using Eigen and S4. R package version, 1(7)

Bellassen V, Viovy N, Luyssaert S, Le Maire G, Schelhaas M-J, Ciais P (2011) Reconstruction and attribution of the carbon sink of European forests between 1950 and 2000. Glob c Biol 17(11):3274-3292

Bouriaud L, Marzano M (2014) Conservation, extraction and corruption: Is sustainable forest management possible in Romania? In: Gilberthrope $E_{i}$ Hilson G (ed) Natural Resource Extraction and Indigenous Livelihoods, Development Challanges in Era of Globalization. Ashgate, London, p 221-240

Bouriaud L, Nichiforel L, Weiss G, Bajaktari A, Curovic M, Dobsinska Z, Glavonjic P, Jarský V, Sarvasova Z, Teder M, Zalite Z (2013) Governance of private forests in Eastern and central Europe: an analysis of forest harvesting and management rights. Ann For Res 56(1):199-215

Bréda N, Granier A, Aussenac G (1995) Effects of thinning on soil and tree water relations, transpiration and growth in an oak forest (Quercus petraea (Matt.) Liebl.). Tree Physiol 15(5):295-306

Burschel P, Huss J (2003) Grundriss des Waldbaus. Ulmer, Stuttgart, p 487

Callister D (1999) Corrupt and Illegal Activities in the Forestry Sector: Current Understandings and Implications for World Bank Forest Policy, Working Paper. World Bank, Washington

Campioli M, Vicca S, Luyssaert S, Bilcke J, Ceschia E, Chapin III FS, Ciais P, Fernández-Martínz M, Malhi Y, Obersteiner M, Olefeldt D, Papale D, Piao SL, Penuelas J, Sullivan PF, Wang X, Zenone T, Janssens IA (2015) Biomass production efficiency controlled by management in temperate and boreal ecosystems. Nat Geosci. doi:10.1038/NGEO2553

Charru M, Seynave I, Morneau F, Bontemps J-D (2010) Recent changes in forest productivity: an analysis of national forest inventory data for common beech (Fagus sylvatica L.) in north-eastern France. For Ecol Manage 260(5):864-874

Contreras-Hermosilla A (2002) Law Compliance in the Forestry Sector: An Overview. WBI Working Papers. World Bank Institute, The World Bank 2002. Also available at: http://documents.worldbank.org/curated/en/2325814687 63471728/Law-compliance-in-the-forestry-sector-an-overview. Accessed July 2016

Coomes AD, Holdaway RJ, Kobe RK, Lines ER, Allen RB (2012) A general integrative framework for modelling woody biomass production and carbon sequestration rates in forests. J Ecol 100:42-64

de Vries W, Solberg S, Dobbertin M, Sterba H, Laubhann D, Van Oijen M, Evans C, Gundersen P, Kros J, Wamelink GWW, Reinds GJ, Sutton MA (2009) The impact of nitrogen deposition on carbon sequestration by European forests and heathlands. For Ecol Manage 258(8):1814-1823

Döbbeler H, Albert M, Schmidt M, Nagel J, Schröder J (2006) BWINPro. Programm zur Bestandesanalyse und Prognose. Handbuch zur Version 6.3. $125 \mathrm{p}$ with a list of allometric functions for single tree volume

Forrester DI, Collopy JJ, Beadle CL, Baker TG (2013) Effect of thinning, pruning and nitrogen fertiliser application on light interception and light-use efficiency in a young Eucalyptus nitens plantation. For Ecol Manage 288:21-30

Goldmann K, Schöning I, Buscot F, Wubet T (2016) Management significantly influences diversity and communities of soil fungi in temperate forests, Soil Biology and Biochemistry., review
Gossner MM, Wende B, Levick S, Schall P, Floren A, Linsenmair KE, Steffan-Dewenter I, Schulze ED, Weisser WW (2016) Exposing logs of 13 tree species in forests shows that maximizing the diversity of deadwood-living species can be achieved using few tree species. Biol Conserv 201:92-102

Hansen AJ, Spies TA, Swanson FJ, Ohmann JL (1991) Conserving biodiversity in managed forests. BioScience 41(6):382-392

Houghton RA (2003) Revised estimates of the annual net flux of carbon to the atmosphere from changes in land use and land management 1850-2000. Tellus B 55(2):378-390

Hynynen J, Salminen H, Ahtikoski A, Huuskonen S, Ojansuu R, Siipilehto J, Lehtonen M, Eerikäinen K (2015) Long-term impacts of forest management on biomass supply and forest resource development: a scenario analysis for Finland. Eur J For Res 134(3):415-431

Janssens IA, Dieleman W, Luyssaert S, Subke JA, Reichstein M, Ceulemans R, Ciais P, Dolman AJ, Grace J, Matteucci G, Papale D, Piao SL, Schulze E-D (2010) Reduction of forest soil respiration in response to nitrogen deposition. Nat Geosci 3(5):315-322

Jucker T, Avăcăriței D, Bărnoaiea I, Duduman G, Bouriaud O, Coomes DA (2015) Climate modulates the effects of tree diversity on forest productivity. J Ecol 104(2):388-398

Kuemmerle T, Hostert P, Radeloff VC, Perzanowski K, Kruhlov I (2007) Post-socialist forest disturbance in the Carpathian border region of Poland, Slovakia, and Ukraine. Ecol Appl 17(5):1279-1295

Kuemmerle T, Hostert P, Radeloff VC, van der Linden S, Perzanowski K, Kruhlov I (2008) Cross-border comparison of post-socialist farmland abandonment in the Carpathians. Ecosystems 11(4):614-628

Lagergren F, Lankreijer H, Kučera J, Cienciala E, Mölder M, Lindroth A (2008) Thinning effects on pine-spruce forest transpiration in central Sweden. For Ecol Manage 255(7):2312-2323

Levick SR, Hessenmoeller D, Schulze ED (2016) Scaling wood volume estimates from inventory plots to landscapes with airborne LiDAR in temperate deciduous forest Carbon Balance Management 11: doi:10.1186/s13021-016-0048-7

Mund M, Kummetz E, Hein M, Bauer GA, Schulze E-D (2002) Growth and carbon stocks of a spruce forest chronosequence in central Europe. For Ecol Manage 171(3):275-296

Nabuurs G-J, Masera O, Andrasko K, Benitez-Ponce P, Boer R, Dutschke M, Elsiddig E, Ford-Robertson J, Frumhoff P, Karjalainen T, Krankina O, Kurz W, Matsumoto M, Oyhantcabal W, Ravindranath NH, Sanz Sanchez MJ, Zhang X, Contribution of Working Group III to the Fourth Assessment Report of the Intergovernmental Panel on Climate Change (2007) Forestry. In: Metz B, Davidson OR, Bosch PR, Dave R, Meyer LA (eds) In Climate Change 2007: Mitigation. Cambridge University Press, Cambridge, United Kingdom and New York

Naudts K, Chen Y, McGrath MJ, Ryder J, Valade A, Otto J, Luyssaert S (2016) Europe's forest management did not mitigate climate warming. Science 351(6273):597-600

Noormets A, Epron D, Domec JC, McNulty SG, Fox T, Sun G, King JS (2015) Effects of forest management on productivity and carbon sequestration: a review and hypothesis. For Ecol Manage 355:124-140

Paillet Y, Berges L, Hjälten J, Odor P, Avon C, Bernhardt-Römermann M, Bijlsma R-J, de Bruyn L, Fuhr M, Grandin U, Kanka R, Lundin L, Luque S, Magura R, Matesanz S, Mészaros I, Sebastia T, Schmidt W, Standovár T, Tóthmérész B, Uotila A, Valladares F, Vellak K, Virtanen R (2010) Biodiversity differences between managed and unmanaged forests: meta-analysis of species richness in Europe. Conserv Biol 24:101-112

Popescu G, Pătrăşcoiu N, Georgescu V (2004) Pădurea şi omul. Editura Nord Carta, Suceava

Pretzsch H, Biber P, Schütze G, Uhl E, Rötzer T (2014) Forest stand growth dynamics in Central Europe have accelerated since 1870. Nat Com 5:4967. doi:10.1038/ncomms5967

Pussinen A, Nabuurs GJ, Wieggers HJ, Reinds GJ, Wamelink GW, Kros J, Mol-Dijkstra JP, De Vries W (2009) Modelling long-term impacts of environmental change on mid-and high-latitude European forests and options for adaptive forest management. For Ecol Manage 258(8):1806-1813

Schelhaas MJ, Nabuurs GJ, Hengeveld G, Reyer C, Hanewinkel M, Zimmermann NE, Cullmann D (2015) Alternative forest management strategies to account for climate change-induced productivity and species suitability changes in Europe. Reg Env Change 15(8):1581-1594

Schulze E-D, Körner C, Law BE, Haberl H, Luyssaert S (2012) Large-scale bioenergy from additional harvest of forest biomass is neither sustainable nor greenhouse gas neutral. Glob Change Biol Bioenergy 4(6):611-616 
Schulze ED, Bouriaud L, Bussler H, Gossner M, Walentowski H, Hessenmöller D, Bouriaud O, van Gadow K (2014) Opinion Paper: Forest management and biodiversity. Web Ecology 14(1):3-10

Schulze E-D, Boch S, Müller J, Levick S, Schumacher J (2016) Die Häufigkeit seltener und gefährdeter Gefäßpflanzen, Moose und Flechten ist im Laubwald unabhängig von Naturschutz und Bewirtschaftung. Allgemeine Forstzeitschrift (in press)

Seidl R, Rammer W, Lexer MJ (2011a) Adaptation options to reduce climate change vulnerability of sustainable forest management in the Austrian Alps. Can J For Res 41(4):694-706, 10.1139/×10-235.

Seidl R, Schelhaas MJ and Lexer MJ (2011b) Unraveling the drivers of intensifying forest disturbance regimes in Europe. Glob Change Biol 17(9):2842-2852

Simonin K, Kolb TE, Montes-Helu M, Koch GW (2007) The influence of thinning on components of stand water balance in a ponderosa pine forest stand during and after extreme drought. Agr For Met 143(3):266-276

Spellmann H, Meesenburg H, Schmidt M, Nagel RV, Sutmöller J, Albert M (2015) Klimaanpassung ist Vorsorge für den wald. ProWald, November 2015, 4-10

TBFRA-2000 (2000) Forest resources of Europe, CIS, North America, Australia, Japan and New Zealand. Nain Report, United Nations, New York, Geneva, page 169

Thueringen Forst (2015) Dienstanordnung Waldbau -2.8: Anweisung zum Waldbau im Staatswald der Landesforschungsanstalt. Thüringen Forst. Erfurt

Thüringer Waldgesetz (2008) From 6th August 1993, renewed GVBI. 2008, p 327

Tupek B, Zanchi G, Verkerk PJ, Churkina G, Viovy N, Hughes JK, Lindner M (2010) A comparison of alternative modelling approaches to evaluate the European forest carbon fluxes. For Ecol Manage 260(3):241-251

van der Plas F, Manning P, Allan E, Scherer-Lorenzen M, Verheyen K, Wirth C, Zavala M, Hector A, Ampoorter E, Baeten L, Barbaro L, Bauhus J, Benavides R, Benneter A, Berthold F, Bonal D, Bouriaud O, Bruelheide H, Bussotti F, Carnol M, Castagneyrol B, Charbonnier Y, Coomes D, Coppi A, Bastias C, Dawud S, De Wandeler H, Domisch T, Finér L, Gessler A, Granier A, Grossiord C, Guyot V, Hattenschwiler S, Jactel H, Jaroszewicz B, Joly F-X, Jucker T, Koricheva J, Milligan H, Müller S, Muys B, Nguyen D, Pollastrini M, Raulund-Rasmussen K, Selvi F, Stenlid J, Valladares F, Vesterdal L, Zielínski D, Fischer M (2016) 'Jackof-all-trades' effects drive biodiversity-ecosystem multifunctionality relationships in European forests. Nat Com 7:11109. doi:10.1038/ ncomms 11109

Vetter M, Wirth C, Böttcher H, Churkina G, Schulze ED, Wutzler T, Weber G (2005) Partitioning direct and indirect human-induced effects on carbon sequestration of managed coniferous forests using model simulations and forest inventories. Glob Change Biol 11(5):810-827

Wirth C, Schumacher J, Schulze ED (2004) Generic biomass functions for Norway spruce in Central Europe-a meta-analysis approach toward prediction and uncertainty estimation. Tree Physiol 24(2):121-139

\section{Submit your manuscript to a SpringerOpen ${ }^{\circ}$ journal and benefit from:}

- Convenient online submission

- Rigorous peer review

- Immediate publication on acceptance

- Open access: articles freely available online

- High visibility within the field

- Retaining the copyright to your article 